\title{
Study on Measurement and Determination Carbon Pool in Traditional Agroforestry System for Handling Climate Change
}

\author{
Jan Willem Hatulesila ${ }^{1}$, Corne lia M.A.Wattimena ${ }^{1}$, Ludia Siahaya ${ }^{1}$ \\ ${ }^{1}$ Forestry Department, Faculty of Agriculture, Pattimura University \\ *Corresponding Author: Jan Willem Hatulesila, Forestry Department, Faculty of Agriculture, \\ Pattimura University.
}

\begin{abstract}
The forest that is the lungs of the world plays a very important role in the continuity of life on earth. Forests absorb $\mathrm{Co}_{2}$ during the process of photosynthesis and decomposition as organic matter in plant biomass. Measurement of forest productivity by biomass measurement. Forest biomass provides important information in the predicted potential of $\mathrm{Co}_{2}$ and biomass sequestration in certain ages that can be used to estimate forest productivity. This research was conducted in the community forest of Hutumuri village as one of traditional agroforestry "dusung" in Ambon Island. Beside that data base can serve as a planner base for the development of large-scale forecasts of carbon stocks for total community forest of agroforestry patterns. The carbon measurement method is done in demonstration plot for tree, sapling and forest floor level. The results show the dominant plant species for plot I in the dominance of nutmeg (Myristica fragrans), plot II durian (Durio zibethinus) and plot III duku (Lansium spp). The total measured biomass on tree vegetation was $58.52 \mathrm{tC} / \mathrm{ha}$; forest floor was $1.71 \mathrm{tC} / \mathrm{ha}$; top soil layer was $13 \mathrm{tC} / \mathrm{ha}$, woody necromass was $33.56 \mathrm{~kg}$ $/ \mathrm{m}^{2}$; rough and soft litter were $1.84 \mathrm{tC} / \mathrm{ha}$, necromass was $67.16 \mathrm{tC} / \mathrm{ha}$. Total biomass of Co2 sequestration in three plots of carbon measurement in community forest of Hutumury Village is 848,62 kg/ m2 or 84,86 tC / ha. It can be classified in the Low Density Forest (HK 1). Therefore it is necessary to increase the cultivation of plants in the community forests of Hutumuri village to meet the requirements of sustainability in the ISCC system.
\end{abstract}

Keywords: carbon pool, carbon sequestration, traditional agroforestry dusung, biomass

\section{INTRODUCTION}

Forests are the lungs of the world play a pivotal role in sustaining life on earth. Forests as part of the ecosystem that is the environment in the course of the reciprocal relationship between living things and their environment. It will be interrupted if one of that ecosystem change. The depletion of the ozone layer can cause a rise in the temperature reaches $40^{\circ} \mathrm{C}$. This had caused the death as happened in India and and several State of the United States. In December 2007 the international community at a conference in Bali agreed through the Bali Road Map to address climate change in 2012. Reducing emissions from forest destruction to try to overcome them globally with a program or mechanism called Reducing Emissions from Deforestation and forest Degradation Plus (REDD +). With REDD + mechanism, the State which succeeded in reducing emissions through improvements in land cover and forests and forest sustainable management will benefit from carbon credits that are kept, so that will optimize the potential of land and forests in various countries including Indonesia.

In general, forests absorb $\mathrm{Co}_{2}$ during photosynthesis and store it as organic matter in biomass plants. The amount of organic matter that is stored in the forest biomass per unit area and per unit of time is the subject of forest productivity. Moreover, forest productivity describes the ability of forests to reduce $\mathrm{Co}_{2}$ emissions in the atmosphere through their physiological activity. Therefore forest productivity measurement is relevant to biomass measurement. In this case, forest biomass provides important information in predicting the magnitude of potential $\mathrm{Co}_{2}$ sequestration and biomass in certain age that can be used to estimate forest productivity.

Method of estimation, measurement, monitoring and reporting of land use, land use change and forests that are so complex to encourage the various parties, including Universities / Research Institutions to find a solution in the implementation of carbon trading. Various attempts were made 
such as the implementation of the certification program and the legality of forestland i.e. man made forest and community forest because of the trees in forest has the ability to produce timber. Generally, mechanism of timber production by the plant requires a lot of energy to absorb $\mathrm{Co}_{2}$ from the air in the process of photosynthesis.

Character conditions of traditional agroforestry ecosystems (namely Dusung) in the Maluku islands with narrow watershed, are particularly vulnerable to global warming or climate change. These conditions also greatly affect the economy and socio-culture (Kastanya et al, 2012). The practice of agroforestry systems in Maluku has been going on for generations and society commonly referred to as Dusung. The establishment of Dusung, is the legacy left by the fathers to the children and grandchildren, in the form of woody plants (trees), fruit trees, sago, palm plants, spices plant or medicinal plants. In general, Dusung in Central Moluccas (such as Ambon Island, Seram Island and Banda Island) located within 1-10 km from the village. This area is wet lowland (0-500 $\mathrm{m}$ above sea level) with the plant fruits such as durian (Durio zibethinus), purple mangos teen (Garciniamangostana), langsat (Lansium parasiticum), pili (Canarium ovatum), spices such as nutmeg (Myristica fragrans) and cloves (Syzygium aromaticum) and also crop such as tubers and bananas (Musa paradisiaca). Principally these plants according to local climatic conditions. Besides that, in general on the riverbanks and wet areas are monoculture tree i.e. sago palm (Metroxylon sagu) and coconut tree (Cocos nucifera), bamboos (Bambusoideae) in coastal and steep area. Besides that, there is birds and mammals in Dusung areas that specific area Wallacea and also endemic in the Maluku archipelago. Although there is no international funding support for REDD + development in the Maluku, a preliminary study on climate change has been carried out such as: the preparation of the allometric equation of young rain tree (Albizia saman (Jacq.) Merr.] (Mardiatmoko, 2016), analysis of carbon-based forest management system (Ie, 2011), mapping of forest biomass distribution (Mardiatmoko , 2012), study of carbon stock estimation in Sirimau Mountain protected forest area (Patampang, 2011) and the determination of biomass classification by using Geographical Information System (Mardiatmoko et al, 2012), and etc. The making of this paper is intended to supplement carbon content information in traditional agroforestry areas adjacent to the Sirimau Mountain protected forest.

\section{Methodology}

The study was conducted in the REDD + scheme. The main goal is to determine the magnitude of changes in carbon emissions from forest conservation and other land use with a system known with MRV (Measurable, Reportable and Verifiable). MRV system itself aims to determine the achievement of performance the implementation of Green House Gasses (GHG) emission reduction through REDD + , as Indonesia's contribution to the target of $26 \%$ reduction on their own and $41 \%$ with international assistance in 2020. The scheme REDD + in Indonesia is illustrated in Figure 1.

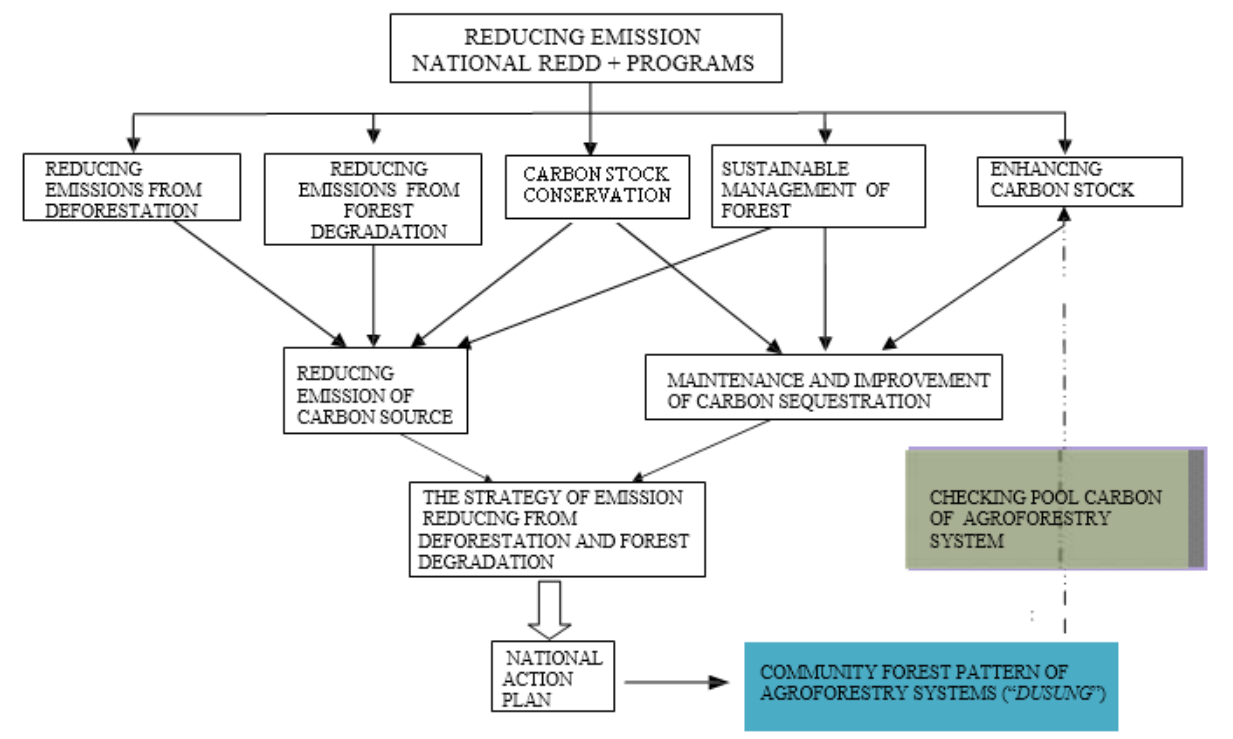

Figure1.Research Based on Indonesia REDDStrategy Scheme(Adapted From Haugland, 2010) Community Forest Pattern ofAgroforestry Systems ("Dusung”) 
This research was conducted in areas agroforestry system belongs to the people in the Hutumuri village, District of South Leitimur, Ambon. The study site is presented in Figure 2.
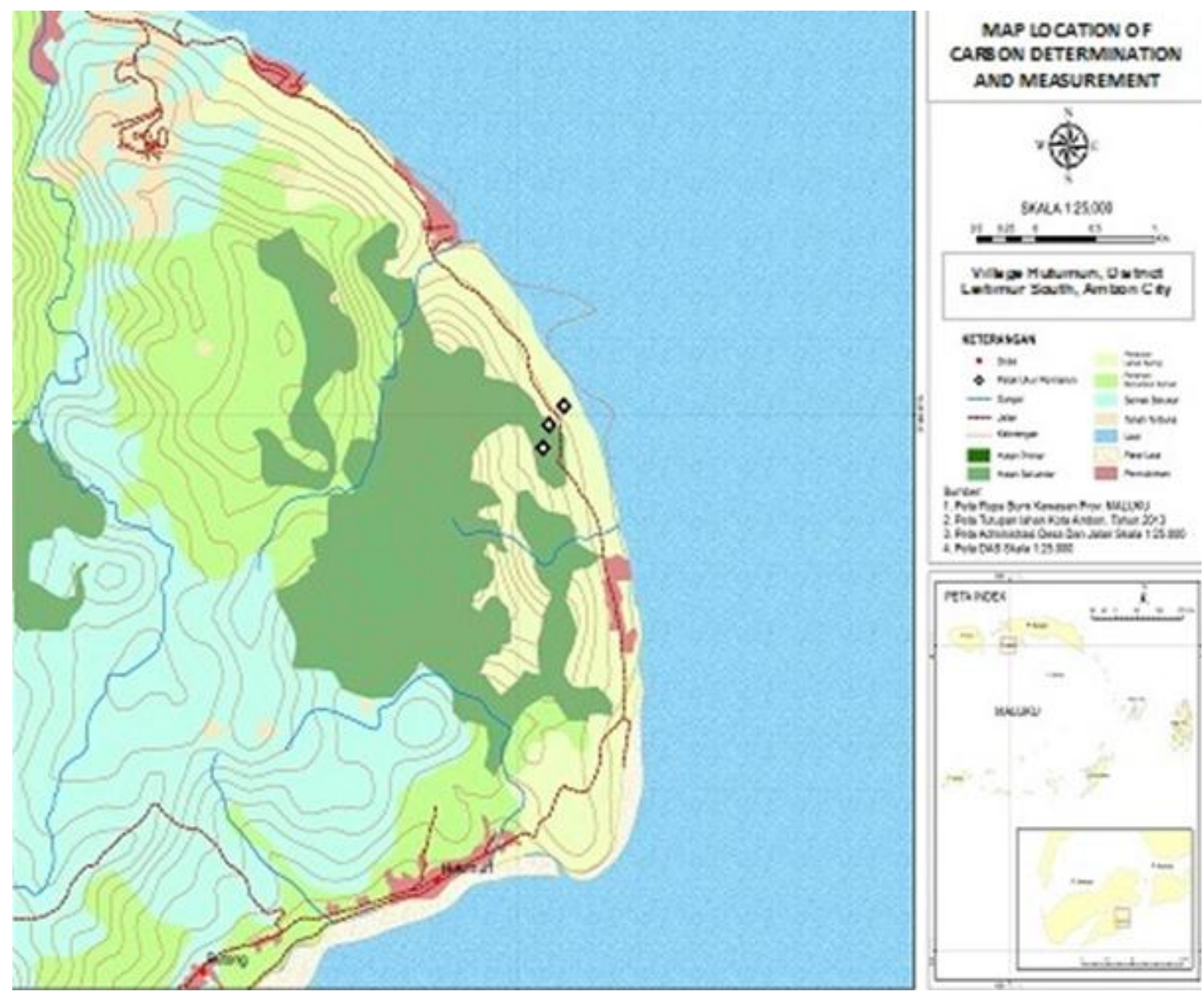

Figure2. Map of Study Site

The Hutumuri village, District of South Leitimur (wide $\pm 15: 00 \mathrm{~km} 2$ ) is located at $3^{\circ} 41^{\prime} 47$ "south latitude up to $128^{\circ} 17^{\prime} 11^{\prime \prime}$ east longitude. The village is situated on the coast of the eastern part of the island of Ambon, precisely in the form of Peninsular Laitimur with mountainous terrain. Location of resident's area as well as the administrative center of the village are in the lowlands. Climate in the Ambon city is type A and the location of Ambon Island surrounded by sea. Vegetation areas in the Hutumuri village vegetated hill forest with plant species, among others: type of plant woody vegetation that is, lenggua (Pterocapus indicus), samama (Samanea saman), pili (C. ovatum), kenanga (Canangium odoratum), bintanggor (Calophylum inophylum), pulai (Alstonia schlolaris), ironwood beach (Insia sp), ketapang (Terminalia catappa) and casuarina beach (Casuarina sp); Vegetation Fruit Crops include mango (Mangifera indica), durian (D. zibhethinus), langsat (L. parasiticum), nutmeg (M. fragans), coconut (C. nucifera), cloves (S. aromaticum) and vegetation shrubs which is dominated by alang-alang (Imperata cilindrica) and ferns (Nephrolepsis exaltata).

Event location mapping Dusung area on the Ambon Island and the division of Dusung area based on the determination of sample plots and classify plant species that exist around the area of sample plots to facilitate recording and measurement. Inventory to assess the potential vegetation based stratification species of plants from the level of seedling, sapling, poles and trees in the research location. It is intended to facilitate the measurement and recordation activities. The method of taking samples and their measurements are presented in Table 1

Table1. The Method of Taking Samples and Their Measurements

\begin{tabular}{|c|c|c|c|}
\hline No & Intake and Measurement of Biomass & Technique intake in ring sample & Remarks \\
\hline A & Organic Material & & \\
\hline & $\begin{array}{c}\text { Vegetation at trees and poles level, } \\
\text { refers to the SNI 7724: 2011 }\end{array}$ & $\begin{array}{c}\text { Vegetation survey at level poles and trees } \\
\text { with an sampling intensity of } 100 \%\end{array}$ & $\begin{array}{c}\text { Taken in all } \\
\text { observation path, }\end{array}$ \\
\hline
\end{tabular}


Study on Measurement and Determination Carbon Pool in Traditional Agroforestry System for Handling Climate

\begin{tabular}{|c|c|c|c|}
\hline & & $\begin{array}{c}\text { (biomas calculations using the equations } \\
\text { allometric with variable diameter at breast } \\
\text { height) }\end{array}$ & $\begin{array}{c}\text { path width and path } \\
\text { length of } 20 \times 20 \mathrm{~m} .\end{array}$ \\
\hline & $\begin{array}{c}\text { Vegetation at seedling and sapling } \\
\text { level, refers to the SNI 7724: 2011 }\end{array}$ & $\begin{array}{c}\text { Taken ring sampling for grass weighing } \\
300 \mathrm{~g} \text { (calculation for the ratio between the } \\
\text { dry weight and the heavy wet) }\end{array}$ & $\begin{array}{c}\text { Ring samples taken } \\
\text { on a plot size } 2 \times 2 \\
\mathrm{~m} ; 5 \times 5 \mathrm{~m} \text { to the } \\
\text { forest floor and } \\
\text { sapling in a plot size } \\
20 \times 20 \mathrm{~m}\end{array}$ \\
\hline B & Litter, Refers to the SNI 7724:2011 & $\begin{array}{c}\text { Taken ring sampling for litter weighing } \\
300 \mathrm{~g} \text { (calculation for the ratio between the } \\
\text { dry weight and the heavy wet) }\end{array}$ & $\begin{array}{c}\text { Ring samples taken } \\
\text { on a plot size } 2 \times 2 \\
\mathrm{~m} \text { to the litter. }\end{array}$ \\
\hline & Deadwood, refers to the SNI 7724: & $\begin{array}{c}\text { The estimation of the volume of deadwood } \\
\text { if it was found in the study site. }\end{array}$ & $\begin{array}{c}\text { Deadwood will be } \\
\text { taken if it is found }\end{array}$ \\
\hline
\end{tabular}

\subsection{Data Analysis Using Some Calculation Methods}

$>$ Mean equation to calculate the data of the ring samples for litter, the biomass of trees, poles, saplings, seedlings and plant ground cover i.e. $\mathrm{X}=\Sigma \mathrm{Xi} / \mathrm{n}$.

$>$ Allometric equations to estimate tree biomass in agroforestry area developed by Ketterings et al. (2001) with the formula: $\mathrm{Y}=\mathrm{a} \rho \mathrm{Db}$, where $\mathrm{a}=$ the interception with the $\mathrm{Y}$ axis; $\mathrm{b}=$ Specific Gravity of wood $\left(\mathrm{g} / \mathrm{cm}^{3}\right) ; \mathrm{D}=\mathrm{DBH}(\mathrm{cm})$ and developed by Chave et al. (2005), namely: $(\mathrm{AGB}) \mathrm{est}=0112(\pi * \mathrm{D} 2 \mathrm{H}) * 0916$.

$>$ The dry weight calculation of litter, forest floor, and a sapling that was developed using the formula Hairiah et al (2011). Total DW (g) = DW subsample (g) / WW subsample (g) x Total weight $(\mathrm{g})$, where $\mathrm{DW}=$ dry weight; and $\mathrm{WW}=$ wet weight.

$>$ Prediction equations for dead wood volume developed by Brown et al (1977), namely: Volume $\left(\mathrm{m}^{3} / \mathrm{ha}\right)=\pi^{2} *\left(\mathrm{D} 1^{2}+\mathrm{D} 2^{2}+\ldots .+\mathrm{Dn}^{2}\right) /(8 * \mathrm{~L})$, where $\mathrm{D}=$ trunk diameter and $\mathrm{L}=$ length of trunk.

$>$ Determination of the potential carbon value in the agroforestry area based on the inventory results of stands. It will be processed and counted to estimate the amount of AGB (aboveground biomass) developed by Brown (1997), namely: $\mathrm{C}=0.5 \mathrm{x} \mathrm{Y}$, where $\mathrm{C}=$ the amount of carbon and $\mathrm{Y}=$ the amount of biomass.

\section{RES ULT AND DIS CUSS ION}

\subsection{Structure and Composition of Trees and Poles in Plot of Carbon Measurement}

Vegetation analysis is commonly used to study the species composition and form or structure of vegetation in the area. We can know the dominant plant species with vegetation analysis, and gave the main characteristics of plant communities at the level of plot. In general, size vegetation dominance is expressed in several parameters such as: biomass, tree height, canopy closure, the important value index (IVI), the important value ratio, etc.Based on the results of inventory types of stands and calculation of IVI to the level of trees and poles on the carbon measurement in Plot I, Plot II and Plot III shows the distribution of plant species according to the composition stands as presented in Table 2 . Iin this case the area of each plot measuring carbon was 0.25 ha

Table2. Value of Stand Density at TreeLevel in ThreePlots of Carbon Measurement

\begin{tabular}{|c|c|c|c|c|c|c|c|c|c|}
\hline No & Trees level & $\sum$ & D & RD & F & RF & C & RC & IVI \\
\hline 1 & Nutmeg (M. fragrans) & 9 & 7,5 & 12,33 & 0,67 & 18,18 & 0,22 & 9,39 & 39,9 \\
\hline 2 & Durian (D. zibethinus) & 27 & 22,5 & 36,99 & 0,67 & 18,18 & 0,73 & 31,47 & 86,6 \\
\hline 3 & Langsat(L. parasiticum) & 6 & 5 & 8,22 & 1 & 27,27 & 0,17 & 7,53 & 43 \\
\hline 4 & Duku (Lansium spp) & 25 & 20,83 & 34,25 & 1 & 27,27 & 0,96 & 41,52 & 103 \\
\hline 5 & Cloves (E. aromatica) & 6 & 5 & 8,22 & 0,33 & 9,09 & 0,23 & 10,09 & 27,4 \\
\hline & Total & $\mathbf{7 3}$ & $\mathbf{6 0 , 8 3}$ & $\mathbf{1 0 0}$ & $\mathbf{3 , 6 7}$ & $\mathbf{1 0 0}$ & $\mathbf{2 , 3 2}$ & $\mathbf{1 0 0}$ & $\mathbf{2 9 9}$ \\
\hline
\end{tabular}

Distribution of the dominant plant species on the third plot to the growth rate of trees is dominated by five types of plants i.e. nutmeg with IVI $=39.9$, durian with IVI $=86.6$, langsat with IVI $=43$, duku 
with IVI $=103$ and cloves with IVI $=27.4$. Based on the results of the calculation of vegetation density, the plants that have the greatest IVI is followed plant of duku, durian and lastly the cloves.

Based on the analysis of vegetation in Table 2, it was concluded that at stand tree level i.e. duku and langsat spread more evenly than other species. It is characterized by a second frequency value categories plant species are larger than most other crops. While durian and duku have more number of species per unit area than other crops so that the density value of the plants also is greater. Besides that duku and durian has a value greater dominance so that the 2 nd species is more dominate on growing space in the community of vegetation for each plot measurements.

Distribution of plants for example at the level of the third plot poles there are 6 types, namely nutmeg, durian, langsat, duku, mangosteen and cloves. Based on calculations IVI, then the plant which has the greatest value of IVI is a type of plant-complexioned with IVI $=92.5$, followed by each type of plant nutmeg with IVI $=60.9$, durian with IVI $=51.4$, duke with IVI $=41.6$, cloves with IVI $=32.5$; and the smallest is the mangos teen with IVI $=21.1$. The distribution of plant species in the three plots measuring carbon disjikan research sites in Table 3.

Table3.Value of Stand Density at Poles Level in Three Plots of Carbon Measurement

\begin{tabular}{|c|c|c|c|c|c|c|c|c|c|}
\hline No & Poles Level & $\sum$ & D & RD & F & zF & C & RC & IVI \\
\hline $\mathbf{1}$ & Nutmeg (M. fragrans) & 22 & 73,33 & 36,07 & 0,67 & 13,33 & 0,28 & 11,51 & 60,9 \\
\hline $\mathbf{2}$ & Durian (D. zibethinus) & 8 & 26,67 & 13,11 & 1 & 20 & 0,45 & 18,29 & 51,4 \\
\hline $\mathbf{3}$ & Langsat (L. domesticum) & 19 & 63,33 & 31,15 & 1 & 20 & 1,01 & 41,37 & 92,5 \\
\hline $\mathbf{4}$ & Duku (Lansium spp) & 5 & 16,67 & 8,2 & 1 & 20 & 0,33 & 13,4 & 41,6 \\
\hline $\mathbf{5}$ & Mangosteen (G. mangostana) & 2 & 6,67 & 3,28 & 0,67 & 13,33 & 0,11 & 4,46 & 21,1 \\
\hline $\mathbf{6}$ & Cloves (E. aromatica) & 5 & 16,67 & 8,2 & 0,67 & 13,33 & 0,27 & 10,98 & 32,5 \\
\hline & Total & 61 & 203,33 & 100 & 5 & 100 & 2,45 & 100 & 321 \\
\hline
\end{tabular}

Based on Table 3, the plant of duku, durian and mangosteen at poles level spread very evenly than other crops. This is indicated by the value of the visible frequency based on measurements and calculations. However, when viewed from the average to the overall distribution of vegetation types, vegetation at poles level are uniform. This is because assessment result for the frequency of all kinds of plants do not show a significant difference. For this type of nutmeg and mangosteen plants have more number of plants per unit of basal area compared with the three other plant species, because the value of the plant density is greater. Besides stand-complexioned and durian plant has a value greater dominance due to the nature and character of the tree which controls most of the vegetation community at the study sites. Basically, an index of species diversity is important information regarding a vegetation community. The wider area of the sample and themore common species in area, the species diversity index values usually tend to be higher. The index value is relatively low diversity are common in communities that have reached the climax. Moreover after the interruption of a vegetation community, there will be an increase in the diversity of species at a point where the community is reaching a climax, and then after the climax there is a trend of diversity index decreased again. For more details, the Diversity Index Level for plot of trees and poles level in Carbon Measurement is presented in Table 4.

Table4. Diversity Index of Trees and Poles Level in Three Plots of Carbon Measurement

\begin{tabular}{|c|c|c|c|c|}
\hline No & Trees Level & $\begin{array}{c}\text { ShannonWiener } \\
\text { Diversity Index (H) }\end{array}$ & Poles Level & $\begin{array}{c}\text { ShannonWiener } \\
\text { Diversity Index (H) }\end{array}$ \\
\hline 1 & Nutmeg (M. fragrans) & 0,26 & Nutmeg (M. fragrans) & 0,37 \\
\hline 2 & Durian (D.zibethinus) & 0,37 & Durian (D. zibethinus) & 0,27 \\
\hline 3 & Langsat(L.parasiticum) & 0,21 & Langsat (L.parasiticum) & 0,36 \\
\hline 4 & Duku (Lansium spp) & 0,37 & Duku (Lansium spp) & 0,21 \\
\hline 5 & Cloves (E. aromatica) & 0,21 & Mangosteen(G.mangostana) & 0,11 \\
\hline 6 & - & - & Cloves (E. aromatica) & 0,21 \\
\hline
\end{tabular}

High diversity of vegetation is usually determined by the number of plant communities are regularly formed at random. Stable, regionally, and homogeneously stable communities, usually have a lower diversity index than forested areas with diverse vegetation. In addition, forests with a larger scale will experience periodic disturbances due to natural factors that occur such as by fire, wind, flood, pest, and human intervention. In the three carbon measurement plots there are stands at the tree level with a 
diversity index value ranging from 0.21 to 0.37 and at the poles level between 0.11 and 0.37 . Based on the criteria of diversity index Shannon-Winer, then to the $2^{\text {nd }}$ level of the growth of these stands have a low diversity. This suggests that the habitat conditions throughout the observation location relatively homogeneous, when viewed from the aspect of disruption to the ecosystem. Thus, in all places in the study site of Hutumuri Village, there was no periodic destruction of forest area. This is understandable because the area is a traditional agroforestry or community forest that has been developed periodically into forest areas that need to be preserved. Thus, to maintain the balance of nature and the needs of the people around the forest area can be fulfilled.

\subsection{Carbon Measurement of Trees Biomass}

The highest carbon values contained in Plot II which is dominated by durian (D. zibethinus) of the family Bombacaceae, in Plot I is dominated Plot dominated by nutmeg (M. fragrans) and in plot III is dominated by duku (Lansium spp). Allegedly high carbon content in durian stands because it has a relatively high specific gravity of wood that is $0.64 \mathrm{~g} / \mathrm{cm}^{3}$, as presented in Table 5 and Figure 3.

Table5. Biomass of Stand at Tree Level In Three Plots of Carbon Measurement

\begin{tabular}{|c|c|c|c|c|}
\hline \multirow{2}{*}{ Plot No. } & \multirow{2}{*}{ Dominant types } & $\begin{array}{c}\text { Average of Diameter } \\
(\mathbf{c m})\end{array}$ & 36.36 & Tree Biomass \\
\cline { 3 - 5 } & & Nutmeg (M. Fragrans) & 42.352 & 4.2352 \\
\hline I & Durian (D. zibethinus) & 37.94 & 70.914 & 7.0914 \\
\hline III & Duku (Lansium spp) & 19.56 & 3.774 & 0.3774 \\
\hline \multicolumn{2}{|c|}{ Total } & 117.04 & 11.704 \\
\hline
\end{tabular}

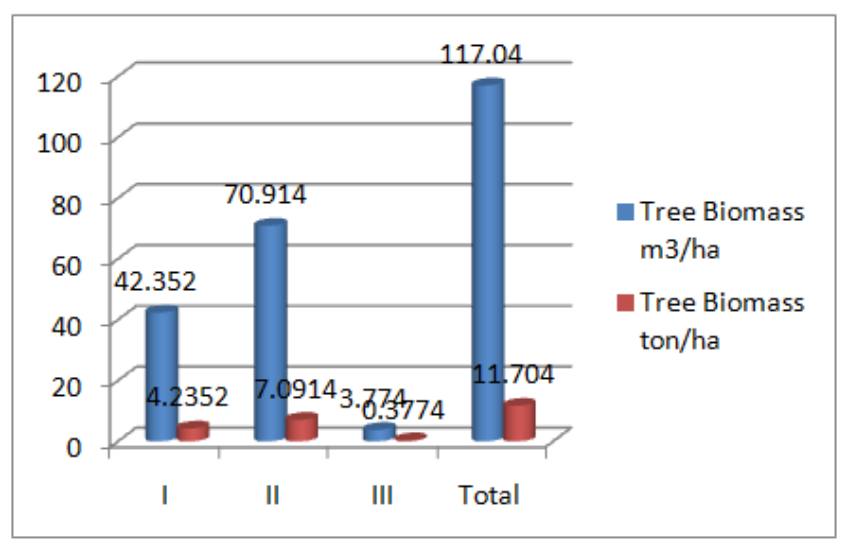

Figure3. Number of Tree Biomasses Each Plot

The measurement results biomass community forests in the village Hutumuri for this type of crop from the three plots measuring at Plot I dominant nutmeg crop value of biomass of $42.35 \mathrm{~kg} / \mathrm{m}^{2}$ and Plot II dominance of durian value of the biomass of $70.91 \mathrm{~kg} / \mathrm{m}^{2}$ and plants duku only amounted to $3,774 \mathrm{~kg} / \mathrm{m}^{2}$. The high amount of biomass in plants durian (D. zibethinus) allegedly due to the size of the diameter, height and wide as the tree canopy codominant plant can reach a diameter of $77.5 \mathrm{~cm}$. As mentioned earlier that the measurement of tree biomass (in dry weight) was calculated using allometric equations based on stem diameter at $1.3 \mathrm{~m}$ height. The same thing also expressed by Rahayu et al (2007) on the results of the estimation of carbon stocks above ground in various land use systems in Nunukan, East Kalimantan Province. It is known that the presence of trees with diameter> $30 \mathrm{~cm}$ in a land use systems provide a significant contribution to total carbon stocks. Based on allometric equation used to calculate the biomass of trees, the intensity of the tree biomass is proportional to the density of the tree. The value of tree biomass also directly proportional to the carbon value, where the higher the value of the biomass, the higher the carbon value. This is due to the value of the carbon content of an organic material is $47 \%$ of the total biomass (BSNI, 2011).

\subsection{Biomass Measurements of Forest Floor, Sapling and Topsoil}

Based on the survey results revealed that the forest floor on a Plot I has the highest carbon stocks are expected because vegetation undergrowth at this location like somewhat open habitat with enough light intensity. The results estimated total biomass of forest floor are presented in Table 6 and Figure 4. 
Study on Measurement and Determination Carbon Pool in Traditional Agroforestry System for Handling Climate

Table6. TotalBiomasss ofForest Floorin ThreePlots of Carbon Measurement

\begin{tabular}{|c|c|c|c|c|c|c|c|}
\hline \multirow{2}{*}{$\begin{array}{c}\text { Plot } \\
\text { No }\end{array}$} & \multirow[t]{2}{*}{ Forest Floor } & \multicolumn{4}{|c|}{ Sapling level } & \multicolumn{2}{|c|}{ Forest floorbiomass } \\
\hline & & Leaves & Trunks & Branch & Twigs & $\mathrm{g} / \mathrm{m}^{2}$ & $\mathrm{~kg} / \mathrm{m}^{2}$ \\
\hline $\mathrm{I}$ & 299 & 2359 & 4670 & 1404 & 774 & 9506 & 23.765 \\
\hline II & 849 & 1133 & 1459 & 356 & 295 & 4092 & 10.23 \\
\hline III & 121 & - & - & - & - & 121 & 0.3025 \\
\hline \multicolumn{7}{|c|}{ Total } & 34.2975 \\
\hline \multirow{2}{*}{\multicolumn{7}{|c|}{$\begin{array}{cc}\text { Totalcarbon } & \text { sequestr } \\
\text { tC/ha }\end{array}$}} & 17.1488 \\
\hline & & & & & & & 1.71 \\
\hline
\end{tabular}

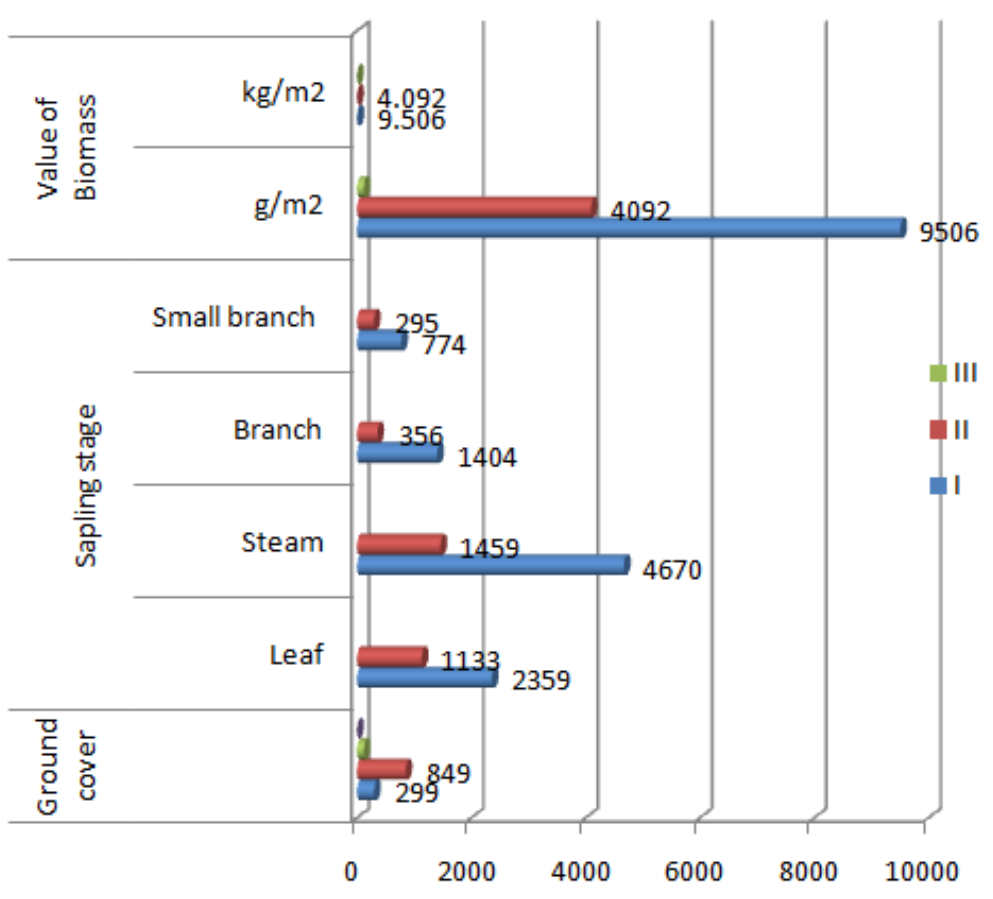

Based on the content of vegetation biomass and forest floor sapling level as measured by dry weight content of the average by the plant i.e. Plot I $=23.76 \mathrm{~kg} / \mathrm{m}^{2}$, Plot II $=10.23 \mathrm{~kg} / \mathrm{m}^{2}$ and Plot III $=0$. $3025 \mathrm{~kg} / \mathrm{m}^{2}$. Average total biomass on forest floor vegetation and sapling level is $34.29 \mathrm{~kg} / \mathrm{m}^{2}$ or amount of carbon uptake is 1.71 tons / ha. Value content of biomass and carbon uptake is presumably due to the influence of light absorption in the process of plant growth and sapling forest floor and level of adaptation to the surrounding environment, especially the canopy of the stands on it greatly affects the development and growth where forest floor. Meanwhile, on Plot III penetration of sunlight to the forest floor less than the Plot I and Plot II because this location has a denser canopy and allelopathy. This resulted in a forest floor that liked open habitats cannot grow well. Moreover crown forest is a limiting factor for plant life, because it can block the penetration of light into the forest floor. It is estimated that dominate the forest floor in Plot III is the kinds of ferns that need shade, like Angiopteris sp.

\subsection{Carbon Measurement of Litter and Deadwood}

The biomass of litter in three plots is presented in Table 7 and Figure 5.

Table7. Biomass of Litter In Three Plots of Carbon Measurement

\begin{tabular}{|c|c|c|c|c|}
\hline \multirow[t]{2}{*}{ Plot No } & \multicolumn{2}{|c|}{ Litter } & \multicolumn{2}{|c|}{ Biomass content } \\
\hline & Soft & Rough & $\mathrm{g} / \mathrm{m}^{2}$ & $\mathrm{~kg} / \mathrm{m}^{2}$ \\
\hline $\mathbf{I}$ & 240 & 5440 & 5680 & 14.2 \\
\hline II & 124 & 3499 & 3623 & 9.0575 \\
\hline III & 322 & 5105 & 5427 & 13.5675 \\
\hline \multicolumn{4}{|c|}{ Total } & 36.825 \\
\hline \multicolumn{4}{|c|}{ Total carbon sequestration $\left(\mathrm{kg} / \mathrm{m}^{2}\right)$} & 18.41 \\
\hline \multicolumn{4}{|c|}{ tC/ha } & 1.84 \\
\hline
\end{tabular}




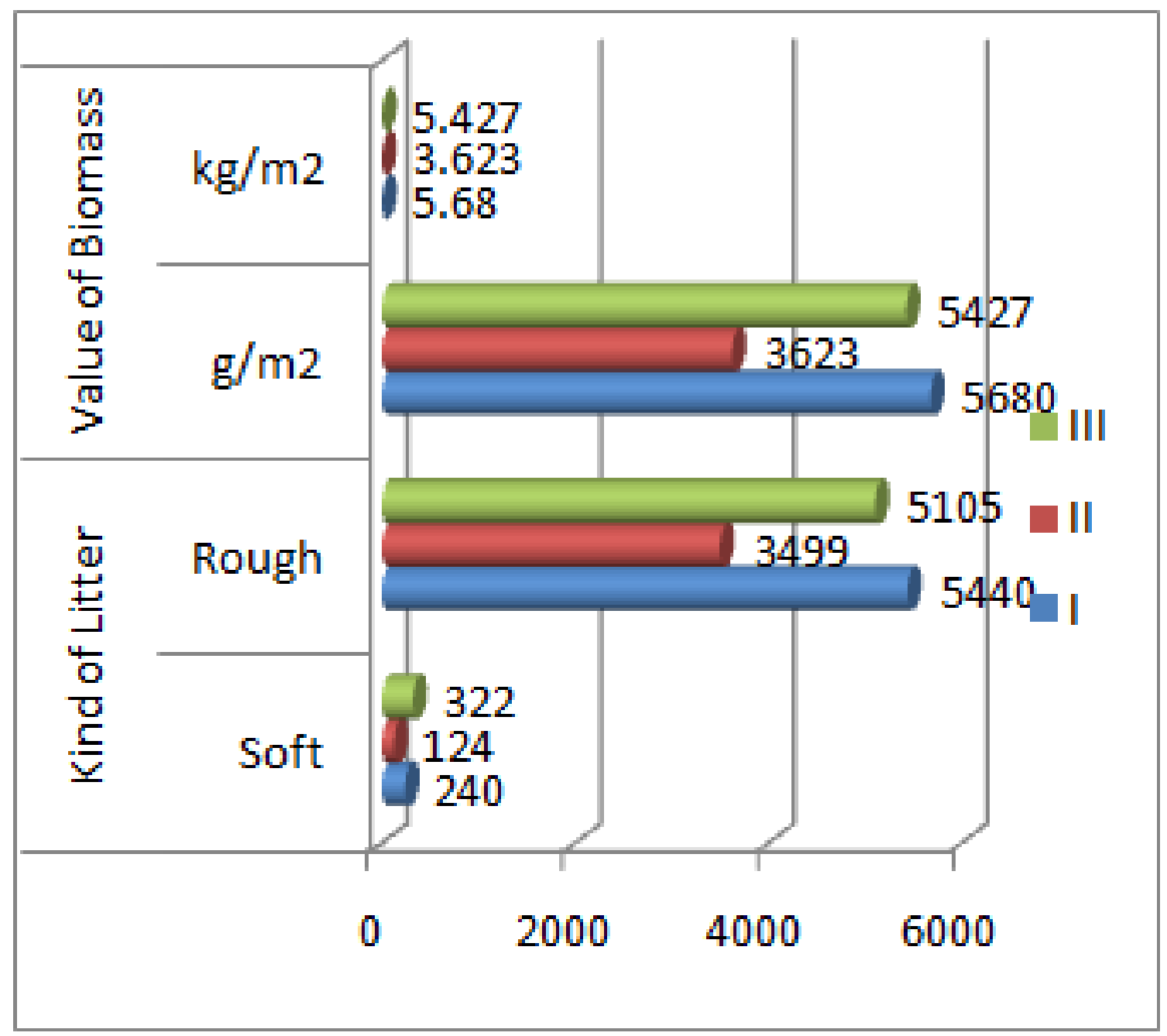

Figure5. Number of Litter Biomasses Each Plot

The results of calculation of dry weight biomass sample of litter was $36.82 \mathrm{~kg} / \mathrm{m}^{2}$ with stored carbon of $1.84 \mathrm{tC} / \mathrm{ha}$. While the results of measurements of plant biomass under can be seen in Table 7 . Deadwood biomass was $671.59 \mathrm{~kg} / \mathrm{m}^{2}$ or $67.16 \mathrm{tC} / \mathrm{ha}$. Results of measurement and weighing-dried samples of demonstration measurements presented in Table 8 and Figure 6.

Table8. Deadwood Biomass In ThreePlots of Carbon Measurement

\begin{tabular}{|c|c|c|c|c|c|c|c|c|}
\hline $\begin{array}{c}\text { Plot } \\
\text { No }\end{array}$ & $\begin{array}{c}\text { Length } \\
1 \text { (cm) }\end{array}$ & $\begin{array}{c}\text { Length } \\
2 \text { (cm) }\end{array}$ & $\begin{array}{c}\text { Length } \\
\text { average } \\
(\mathrm{cm})\end{array}$ & $\begin{array}{c}\mathbf{T} \\
(\mathbf{m})\end{array}$ & $\begin{array}{l}\text { Diame } \\
\text { ter } \\
(\mathrm{cm}) \\
\end{array}$ & $\begin{array}{c}\text { Wood density } \\
\text { ofdeadwood } \\
\left(\mathrm{g} / \mathrm{cm}^{3}\right)\end{array}$ & $\begin{array}{l}\text { Percentage of } \\
\text { decomposition }\end{array}$ & $\begin{array}{c}\text { Value of } \\
\text { Necromass } \\
\left(\mathrm{kg} / \mathrm{m}^{2}\right) \\
\end{array}$ \\
\hline 1 & 4 & 2.5 & 5.25 & 180 & 27.56 & 0.4 & $50 \%$ & 54.35 \\
\hline 2 & 13 & 6 & 16 & 95 & 256 & 0.4 & $40 \%$ & 403.87 \\
\hline 3 & 4.5 & 2 & 5.5 & 85 & 30.25 & 0.4 & $50 \%$ & 59.65 \\
\hline & & & & & & & Total & 517.87 \\
\hline 1 & 5 & 2.5 & 6.25 & 100 & 39.06 & 0.4 & $50 \%$ & 77.03 \\
\hline 2 & 6.5 & 3 & 8 & 90 & 64 & 0.4 & $50 \%$ & 126.21 \\
\hline 3 & 8 & 5 & 10.5 & 42 & 110.25 & 0.4 & $50 \%$ & 217.41 \\
\hline & & & 0 & & & & Total & 420.65 \\
\hline 1 & 17 & 4 & 19 & 56 & 361 & 0.4 & $20 \%$ & 284.76 \\
\hline 2 & 5 & 2 & 6 & 70 & 36 & 0.4 & $30 \%$ & 42.60 \\
\hline 3 & 4 & 6 & 7 & 35 & 49 & 0.4 & $40 \%$ & 77.30 \\
\hline \multicolumn{8}{|c|}{ Total } & 404.65 \\
\hline \multicolumn{8}{|c|}{ Total Necromass $\left(\mathrm{kg} / \mathrm{m}^{2}\right)$} & 1343.18 \\
\hline \multicolumn{8}{|c|}{ Total Carbon Sequestration $\left(\mathrm{kg} / \mathrm{m}^{2}\right)$} & 671.59 \\
\hline \multicolumn{8}{|c|}{ tC/ha } & 67.16 \\
\hline
\end{tabular}




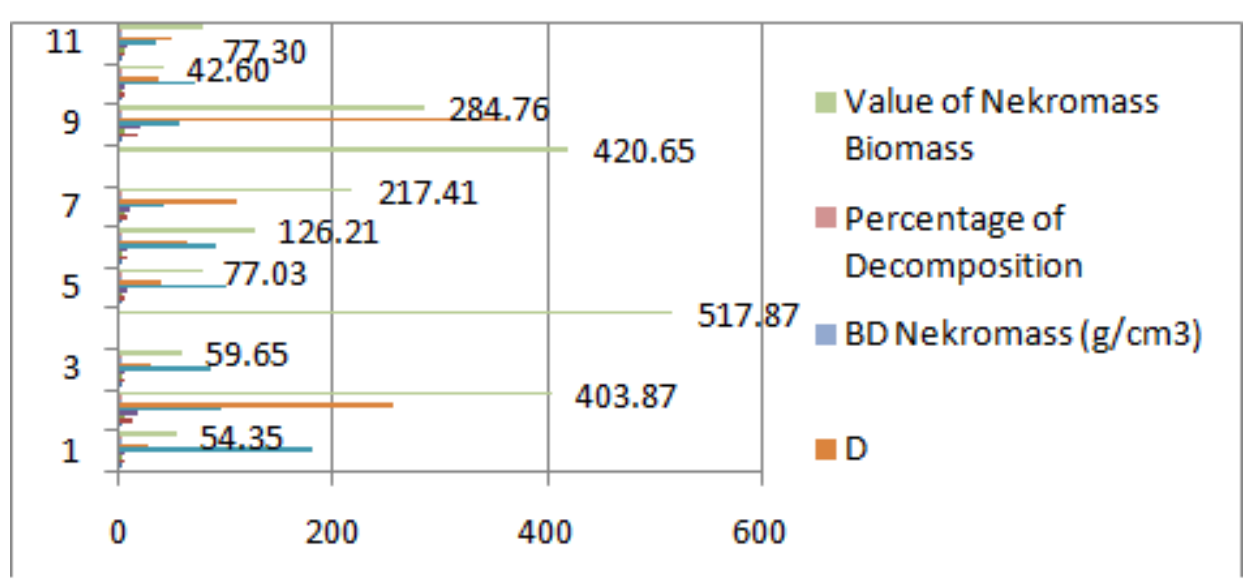

Figure7. Number of Deadwood Biomass on Each Plot

According to the results of measuring and calculating for the above-ground biomass at litter and necromass, community forest in Hutumuri village still has a number of carbon reserves that meet the recommendations of the Intergovernmental Panel on Climate Change (IPCC).

\subsection{Co2 sequestration of Trees and Poles level in Three Plots}

Based on research result from Rahayu et al. (2007) about the content of the above-ground biomass for live and dead trees, undergrowth and litter on various land use systems in Nunukan, East Kalimantan was 230.1 tons / ha in primary forest, 206.8 tons / ha in logged forest 0-10 years, 212.9 tons / ha in logged forest $11-30$ years and 184.2 tons / ha in logged forest 31-50 years. Based on the research results can be seen that the amount of biomass for the land area of $1,200 \mathrm{~m}^{2}$ has an average biomass of $585.20 \mathrm{~kg} / \mathrm{m}^{2}$. Thus the total $\mathrm{Co}_{2}$ sequestration by tree vegetation per hectare in the study site can be assumed to be $58.52 \mathrm{tC} /$ ha as presented in Table 9 and Figure 8.

Table9. Stand Biomass at Tree And Poles Level in Three Plots of Carbon Measurement

\begin{tabular}{|c|c|c|c|}
\hline Plot No & Stand of tree and poles level & $\sum$ Volume $\left(\mathrm{m}^{3}\right)$ & $\sum$ Biomass $\left(\mathrm{kg} / \mathrm{m}^{2}\right)$ \\
\hline I & Nutmeg, durian and langsa & 14.088 & 423.52 \\
\hline II & Durian, duku, nutmeg and langsa & 24.038 & 709.14 \\
\hline III & Duku, cloves, durian, langsa and nutmeg & 1.385 & 37.75 \\
\hline & Totalbiomass & 39.511 & $1,170.41$ \\
\hline \multicolumn{3}{|c|}{ Average biomass } & 585.20 \\
\hline
\end{tabular}

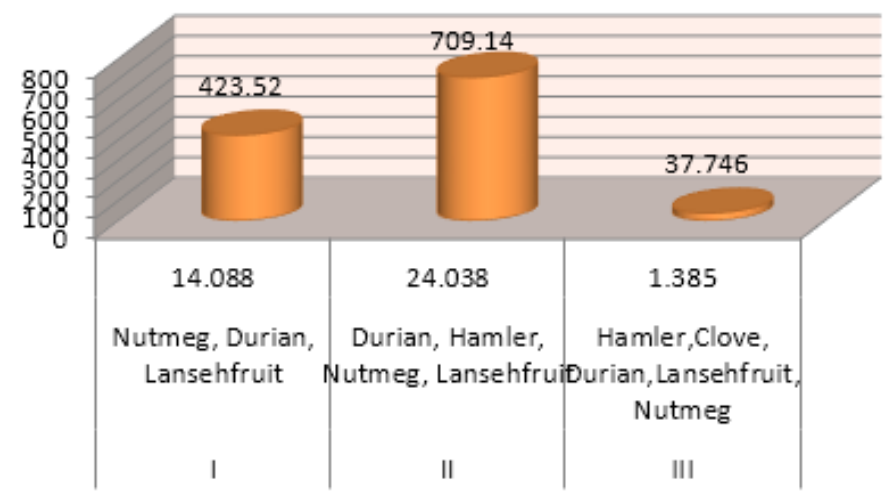

$\square \Sigma$ Biomass

$\mathrm{CO}_{2}$ sequestration by trees in the village of Hutumuri relatively low when compared to the sequestration ofCo2 by the forests of the production of Siberut Island Biosphere Reserve in West Sumatra Province. Based on research Bismark et al. (2008) showed that the $\mathrm{Co}_{2}$ sequestration by trees with $\mathrm{dbh}>5 \mathrm{~cm}$ in primary forests was 242.07 tons / ha. When compared with the density in primary forest of Siberut Island Biosphere Reserve is 114.25 trees / ha. From these explanations it can be stated that forest community in the study site can be classified as low-carbon biomass. It contains an average of corresponding distribution rate of tree stands and poles that dominate the community forest area. 


\subsection{Estimated Total Carbon Stocks in Above-Ground Biomass in three plots}

Carbon stocks can be interpreted abundance of carbon that can be absorbed by plants in the form of biomass. Forest biomass can be used to infer the content of carbon in forest vegetation, because vegetation biomass carbon contained about 50\% (Brown et al, 1989). The amount of carbon emissions are increasing at present must be balanced with the amount of absorption, it was necessary to reduce the impact of global warming by planting trees as much, because the tree through photosynthesis can convert $\mathrm{Co}_{2}$ into $\mathrm{O}_{2}$. Condition of plant species is dominated by varieties of fruit crops in which the measurement results and the estimation of the total carbon in above-ground biomass as presented in Table 10.

Table10. Estimated Total Carbon Stocks in Three Plots of Carbon Measurement

\begin{tabular}{|c|c|c|c|c|c|c|c|}
\hline $\begin{array}{c}\text { Plot } \\
\text { No }\end{array}$ & $\begin{array}{c}\text { Trees } \\
\left(\mathrm{kg} / \mathrm{m}^{2}\right)\end{array}$ & $\begin{array}{c}\text { Forest } \\
\text { floor\&sapling } \\
\left(\mathrm{kg} / \mathrm{m}^{2}\right) \\
\end{array}$ & $\begin{array}{c}\text { Deadw } \\
\operatorname{ood}(\mathbf{k g} / \\
\left.\mathbf{m}^{2}\right) \\
\end{array}$ & $\begin{array}{c}\text { Litter } \\
\left(\mathrm{kg} / \mathrm{m}^{2}\right)\end{array}$ & $\begin{array}{c}\text { Topsoil } \\
(030 \mathrm{~cm}) \\
\left(\mathrm{kg} / \mathrm{m}^{2}\right) \\
\end{array}$ & $\begin{array}{l}\text { Total Biomass } \\
\text { x } 46 \%\left(\mathrm{~kg} / \mathrm{m}^{2}\right)\end{array}$ & $\begin{array}{l}\text { Total Carbon } \\
\text { Stock }\left(\mathrm{kg} / \mathrm{m}^{2}\right)\end{array}$ \\
\hline $\mathrm{I}$ & 211.76 & 76 & 258.94 & 5.68 & 75 & 627.38 & 288.59 \\
\hline II & 354.57 & 38.5 & 210.33 & 3.62 & 64 & 671.02 & 308.67 \\
\hline III & 188.7 & 28 & 202.33 & 5.42 & 122 & 546.45 & 251.36 \\
\hline \multicolumn{7}{|c|}{ Total carbon stock } & 848.62 \\
\hline \multicolumn{8}{|c|}{ or $84.86 \mathrm{tC} / \mathrm{ha}$} \\
\hline
\end{tabular}

Based on the table 10 total carbon measurement on three plots was $848.62 \mathrm{~kg} / \mathrm{m}^{2}$ or $84.86 \mathrm{tC} / \mathrm{ha}$. With regard to it, this region into the category of Low Density Forest (HK 1). This is according to a research report from Greenpeace (2013). In the report stated Forest Density Medium (HK 2) is remaining natural forest, but the condition is more disturbed than High Density Forest (HK 3) and has an carbon average $166 \mathrm{tC} / \mathrm{ha}$. While the Low Density Forest (HK 1) looks like the rest of the forest, but the conditions are very disturbed and recovery and have an average of $107 \mathrm{tC} /$ ha. Both strata of these forests belong to the category of high carbon value. Hairiah and Rahayu (2007) also states that the concentration of carbon in organic matter (biomass) is usually around $46 \%$. In general, carbon stored in a forest community is also influenced by the diameter and density of plants. Differences in density of plant species every location measurement studies of carbon would be estimated how many trees must be planted on an area of land to offset the amount of carbon that is free in the air. A system of forest community consisting of tree species that have a density value of the wood is high then the biomass will be higher when compared with community forests with tree species by value of wood density is low. Therefore it is necessary to increase the cultivation of plants in the community forests of Hutumuri village to meet the requirements of sustainability in the International Sustainability and Carbon Certification (ISCC) system (ISCC, 2017).

\section{CONCLUSion}

The results of measurements of biomass at the level of tree stands and poles (in plot of $20 \times 20 \mathrm{~m}$ ) amounted to $117.04 \mathrm{~m}^{3} / \mathrm{ha}$; forest floor (in plot of $2 \times 2 \mathrm{~m}$ and $5 \times 5 \mathrm{~m}$ ) was $13.719 \mathrm{~kg} / \mathrm{m}^{2}$, woody necromass was $1343.18 \mathrm{~kg} / \mathrm{m} 2$; rough and soft litter were $14.73 \mathrm{~kg} / \mathrm{m}^{2}$. Besides that, the estimation of $\mathrm{Co}_{2}$ sequestration for carbon stocks on the surface of three plots with plot size $20 \mathrm{x} 20 \mathrm{~m}$ in an area of 0.12 ha has an carbon sequestration by $848.62 \mathrm{~kg} / \mathrm{m} 2$ or 84.86 Cton / ha. Therefore, based on classification of forest with high stock carbon from Greenpeace (2013) it can be classified in the Low Density Forest (HK 1). Thus, it is necessary to increase the cultivation of plants in the community forests of Hutumuri village to meet the requirements of sustainability in the ISCC system (ISCC, 2017).

\section{ACKNOWLEDGEMENT}

The author thanks the Directorate General of Research and Development, The Ministry of Research, Technology and Higher Education, Republic of Indonesia for funding the study through the 20152016 research scheme of Hibah Bersaing.

\section{REFERENCES}

[1] Bismark, M., Subandiono, E., Heriyanto, N.M. 2008. Keragaman dan potensi jenis serta kandungan karbon hutan mangrove di Sungai Sibelen Siberut Sumatera Barat. Jurnal Penelitian Hutan dan Konservasi Alam 5 (3): $297-306$ 
[2] Brown, S., Gillespie, A.J.R., Lugo, A.E. 1989. Biomass estimation methods for tropical forests with application to forest inventoty data. Forest Science 35 (4): 881-902.

[3] Brown, J.K., Snell, J.A.K., Bunnell, D.L. 1977. Handbook for predicting slash weight of western conifers. General Technical Report INT-37. USDA Forest Service. Utah.

[4] Brown, J.K.1997. Estimating Biomass and Biomass Change of Tropical Forest. A. Primer. FAO Forestry paper. Rome. Italy.

[5] BSNI. 2011. SNI 7725: Penyusunan Persamaan Alometrik untuk Penaksiran Cadangan Karbon Hutan berdasar Pengukuran Lapangan (Ground Based Forest Carbon Accounting). Badan Standarisasi Nasional Indonesia. Jakarta.

[6] Chave, J., Andalo, C., Brown, S., Cairns, M.A., Chambers, J.Q., Eamus, D., Folster, H., Fromard, F., Higuchi, N., Kira, T., Lescure, J.P., Nelson, B.W., Ogawa, H., Puig, H., Riera, B.

[7] Yamakura, T. 2005. Tree allometry and improved estimation of carbon stocks and balance in tropical forests. Oecologia 145: 87-99.

[8] Greenpeace. 2013. RingkasanGreenpeaceHutanBer-StokKarbonTinggi: Identifikasi hutan ber-stok karbon tinggi untuk perlindungan pada hutan alam dan lahan terdegradasi (hutan bekas tebangan) di daerah tropis. https://goldenagri.com.sg/pdfs/misc/HCS/Briefer/FINAL/with/graphic/IND/REVISED.pdf （ accessed February 1, 2018)

[9] Hairiah, K., Ekadinata, A., Sari, R.R., Rahayu, S. 2011. Pengukuran cadangan karbon dari tingkat lahan ke bentang lahan. Edisi 2. World Agroforestry Centre, ICRAF Southeast Asia dan Universitas Brawijaya. Bogor dan Malang. Indonesia.

[10] Haugland, S. 2010. Development of Indonesia's National REDD+ Strategy. UN-REDD Regional Information Exchange $\quad$ Meeting, $\quad$ Bangkok, $10 \quad$ November 2010. http://www.unredd.net/index.php?option=com_docman\&task=doc (accessed February 8, 2018)

[11] Ie, S. 2011. Analisis sistem pengelolaan hutan berbasis karbon pada IUPHHK-HA PT. Gema Hutan Lestari, Pulau Buru-Provinsi Maluku. Program Pascasarjana UNPATTI. Thesis.

[12] ISCC. 2017. Providing sustainability solutions for fully traceable and deforestation free supply chains. The International Sustainability and Carbon Certification. https://www.iscc-system.org/ (accessed February 1, 2018)

[13] Kastanya. A, Mardiatmoko. G and Loppies. R. 2012. Strategi Pengembangan Redd+ Di Provinsi Maluku. Materi Presentasi disampaikan pada University Forum and UN-REDD Lesson Learned. Palu, 23-24 Oktober 2012

[14] Ketterings, Q.M., Coe, R., van Noordwijk, M., Ambagau, Y., Palm, C.A. 2001. Reducing uncertainty in the use of allometrics biomass equation for predicting above-ground tree biomass in mixed secondary forests. Forest Ecology and Management 146: 199-209.

[15] Mardiatmoko, G. 2012. Pemetaan Distribusi Biomassa Hutan dan Kaitannya dengan Suhu dan Intensitas Cahaya Melalui Pendekatan Sistem Informasi Geografi. Journal of Biota 17 (1) : 35-44.

[16] Mardiatmoko, G., Silaya, T.M. Hatulesila, J.W. 2012. Study on application of Geographical Information System (GIS) for establishment of biomass classification to support implementation of clean development mechanism. Agrivita 34 (1) : 1-6

[17] Mardiatmoko, G. 2016. Allometric equations for predicting above and below-ground biomass of young rain tree [Albizia saman (Jacq.) Merr.] to handle climate change. AsianJrofMicrobiol.Biotech.Env.Sc. Vol.18,No.(4): 821-830

[18] Rahayu, S, B. Lusiana, dan M. van Noordwijk. 2007. Pendugaan Cadangan Karbon di Atas Permukaan Tanah Pada Berbagai Sistem Penggunaan Lahan di Kabupaten Nunukan, Kalimantan Timur. Bogor: World Agroforestry Centre.

[19] SNI 7724.2011. Pengukuran dan penghitungan cadangan karbon -Pengukuran lapangan untuk penaksiran cadangan karbon hutan (ground based forest carbon accounting). http://sisni.bsn.go.id/index.php/sni_main/ sni/detail_sni/13949 (accessed February 8, 2018)

Citation: Jan W. H. et al., "Study on Measurement and Determination Carbon Pool in Traditional Agroforestry System for Handling Climate Change", International Journal of Forestry and Horticulture, vol. 4, no. 2, p. 14-24, 2018. http://dx.doi.org/10.20431/2454-9487.0402003

Copyright: (C) 2018 Authors. This is an open-access article distributed under the terms of the Creative Commons Attribution License, which permits unrestricted use, distribution, and reproduction in any medium, provided the original author and source are credited. 